\title{
GOSPODAROWANIE KAPITAŁEM LUDZKIM W ŚWIETLE ORGANIZACYJNO-PRAWNYM SZANSE I ZAGROŻENIA
}

\author{
WSTĘP
}

Niniejszy referat podejmuje problematykę zarządzania ludźmi w organizacji. Jego celem jest przedstawienie założeń dotyczących gospodarowania kapitałem ludzkim, takich jak: budowanie lojalności pracowników, motywowanie, wspieranie. W referacie przedstawiono metody, a także rodzaje oceniania oraz wynagradzania. Została również poruszona tematyka związana z elastycznymi, nowoczesnymi formami zatrudnienia pracowników. Problem ukazano z perspektywy zachowań organizacyjnych oraz regulacji stosunków prawnych między pracodawcą a pracownikiem.

\section{DEFINICJA KAPITAŁU LUDZKIEGO}

Kapitał ludzki to pojęcie bardzo szeroko omawiane, mimo to nie ma jednoznacznej definicji, która określałaby ten termin. Definicja kapitału ludzkiego w ujęciu Schultza zakłada, że „kapitał ludzki będą stanowić cechy ludzkie, które są cenione i mogą być rozwijane dzięki odpowiednim inwestycjom"1. Według Bontisa i jego współpracowników, kapitał ludzki można rozumieć jako „odzwierciedlenie czynnika ludzkiego w organizacji. Kapitał ludzki stanowi połączenie inteligencji, umiejętności i fachowości"2. Natomiast J. Grodzicki wyróżnia kapitał ludzki sensu largo jako ogół walorów ludzkich, który jest efektem procesu adaptacji, cech własnych oraz procesu

* Studentka, Uniwersytet Łódzki.

1 T.W. Schultz, Investment in Human Capital, „American Economic Review”, Vol. 1, No. 2, 1961, za: M. Armstrong, Zarządzanie zasobami ludzkimi, Kraków 2007, s. 323.

2 N. Bontis, N.C. Dragonetti, K. Jacobsen, G. Roos, The Knowledge Toolbox: A Review of the Tools Available to Measure and Manage Intangible Resources, „European Management Journal”, Vol. 17, No. 4, 1999, s. 391-402, za: M. Armstrong, Zarządzanie..., s. 323. 
kształcenia, a także kapitał ludzki sensu stricto, który wyraża wartości wynikające z sumy nakładów na kształcenie jednostki. Suma ta składa się na potencjał edukacyjny całego społeczeństwa ${ }^{3}$.

Zgodnie z powyższymi definicjami, można uznać, że kapitał ludzki to ludzie związani z daną organizacją.

Z kolei gospodarowanie zasobami ludzkimi, to według Amstronga „strategiczne i spójne podejście do zarządzania najbardziej wartościowymi aktywami organizacji ludźmi, którzy w danej organizacji pracują oraz indywidualnie i zbiorowo przyczyniają się do realizacji jej celów"4. Z kolei A. Pocztowski proponuje określenie zasobów ludzkich jako „koncepcję zarządzania w obszarze funkcji personalnej przedsiębiorstw, w której pełnią rolę składnika aktywów firmy i źródła konkurencyjności". Pocztowski twierdzi również, że „narzędziem do osiągania celów jest przede wszystkim budowanie zaangażowania pracowników" ${ }^{5}$.

Współczesny świat stanowi duże wyzwanie dla powstających, rozwijających się i istniejących już przedsiębiorstw na rynku. Wszyscy uczestnicy rynku pracy stają przed kluczowymi pytania: Jak zatrzymać najlepszych pracowników? Jak przyciągać nowych, kreatywnych? W jaki sposób budować lojalność i zaangażowanie zespołu w organizacji? Borykają się z trudnościami związanymi z efektywną metodą oceny pracowników, z właściwymi metodami wynagradzania. Trudności te w jakimś stopniu mogą mieć wpływ na wzrost zatrudnienia na podstawie umów cywilnoprawnych, a zmniejszeniem się liczby umów regulowanych stosunkiem pracy.

\section{DETERMINANTY WARUNKUJĄCE EFEKTYWNE ZWIĘKSZENIE ZASOBÓW LUDZKICH W ORGANIZACJI}

Podstawą działania każdej firmy i organizacji powinno być wyrobienie silnej marki, czyli budowanie wizerunku pracodawcy (employer branding). Jeśli przedsiębiorstwo zadba o odpowiednią prezentację marki oraz zapewni sobie dobrą reputację, wówczas osiągnie pierwszy stopień w zaistnieniu na rynku oraz w pozyskaniu pracowników. Kolejnym aspektem, który powinna uwzględnić organizacja, szczególnie pod kątem utrzymania oraz pozyskania najlepszych pracowników, jest komunikacja z otoczeniem. Rozwijając to pojęcie warto nawiązać do definicji public relations B. Rozwadowskiej, według której PR to „funkcja zarządzania komunikacją między organizacją a jej otoczeniem (zarówno wewnętrznym, jak i zewnętrznym), która ma

3 J. Grodzicki, Rola kapitału ludzkiego w rozwoju gospodarki globalnej, Wydawnictwo Uniwersytetu Gdańskiego, Gdańsk 2003, s. 50.

${ }_{4}$ M. Armstrong, Zarządzanie..., s. 29.

5 H. Król, A. Ludwiczyński, Zarządzanie zasobami ludzkimi. Tworzenie kapitału ludzkiego organizacji, Wydawnictwo Naukowe PWN, Warszawa 2006, s. 55. 


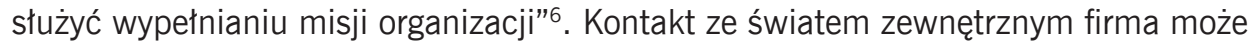
podtrzymywać poprzez aktywne działanie w świecie - współpracę z uczelniami wyższymi, organizację szkoleń rozwojowych, atrakcyjne programy staży oraz praktyk, a także poprzez media, dzięki którym młode pokolenie poznaje szeroki asortyment możliwości rozwojowych.

Równocześnie organizacja nie może ignorować czynników wewnętrznych, które pomogą w zatrzymaniu kapitału ludzkiego w jej szeregach. Kadry menedżerskie nie zawsze są świadome, jak istotny jest wspieranie pracowników oraz docenianie ich działań.

W skutecznym budowaniu relacji firma-pracownicy mogą pomóc narzędzia, którymi w obszarze Human Resources posługują się międzynarodowe przedsiębiorstwa. Należy do nich m.in.: feedback, czyli tzw. ocena 360 stopni, czy inaczej - wielopodmiotowy system oceniania pracownika, ustalany na podstawie informacji o nim z wielu źródeł, w tym również samoocen ${ }^{7}$ oraz model cloud computing - chmura obliczeniowa, system przetwarzania danych, który umożliwia dostęp przez Internet do współdzielonej puli zasobów obliczeniowych, co w sposób pośredni wpływa na zadowolenie pracownika z pracy w danej organizacji. Ponadto niezwykle ważną kwestią jest, by pracownik miał poczucie, że jest niezbędny dla firmy, że stanowi jej istotną część, a nie jest przysłowiowym pionkiem. Ważnym czynnikiem dla przedsiębiorstw dbających o swoją renomę jest również sformalizowana strategia w obszarze CSR (Corporate Social Responsibility), tzw. filozofia prowadzenia biznesu. Zakłada ona dbanie nie tylko o dobre relacje firmy z jej klientami i akcjonariuszami, ale również z pracownikami, dostawcami, społecznościami lokalnymi. Jednym z ważniejszych obszarów CSR, często ignorowanym przez mniejsze firmy, jest ochrona środowiska naturalnego ${ }^{8}$.

\section{CZYNNIKI ZWIĘKSZAJĄCE ZAANGAŻOWANIE I LOJALNOŚĆ PRACOWNIKÓW}

Kolejnym aspektem, który wpływa na efektywne funkcjonowanie organizacji jest potrzeba budowania zaangażowania oraz lojalności wśród pracowników względem firmy, w której działają. We współczesnym świecie, gdzie niepewność zatrudnienia wzrasta, tym bardziej powinno się zwiększyć nacisk na zadowolenie pracownika z pracy w danej organizacji, by zapobiec nadmiernej fluktuacji personelu, która wiązałaby się de facto ze spadkiem efektywności przedsiębiorstwa. W tym celu można

6 Preals Public Relations, http://preals.pl/predu/definicja-pr [dostęp: 16.10.2014].

7 M. Armstrong, Zarządzanie..., s. 466.

8 http://forbes.pl/artykuly/sekcje/baza-wiedzy-csr/czym-jest-odpowiedzialnosc-spolecznabiznesu-csr--ang--corporate-social-responsibility-,3878,1\# [dostęp: 15.10.2014]. 
oprzeć się o systemy motywacyjne, które w znacznym stopniu oddziałują na jakościowe wykonanie powierzonych pracownikom zadań. Narzędzia motywacji pracowników dzielą się na trzy podstawowe grupy:

- środki przymusu - przyjęcie postawy narzucającej względem pracownika,

- środki zachęty - nagradzanie za oczekiwane zachowanie,

- środki perswazji, które odwołują się do zmiany postaw i zachowań ludzi, a także do przyjęcia określonego modelu postępowania, który będzie pożądany dla obu stron ${ }^{9}$.

Niezwykle istotny element o charakterze motywacyjnym stanowi system wynagradzania. Jest on zapłatą za pracę podporządkowaną bądź świadczoną na rzecz pracodawcy $^{10}$. Obowiązek zapłaty wynagrodzenia jest cechą każdego stosunku pracy. Konkretne rozwiązania w zakresie wynagrodzenia regulują zbiorowe układy pracy lub regulamin wynagradzania. Warto wspomnieć o dwóch z czterech podstawowych funkcji wynagrodzeń, mianowicie o funkcji motywacyjnej oraz społecznej, gdyż z punktu widzenia kapitału ludzkiego te dwie funkcje mają zasadnicze znaczenie w budowaniu zaangażowania i lojalności zespołu.

Funkcja motywacyjna składa się z subfunkcji: wynagrodzenie skłania ludzi do podjęcia określonej pracy. Fluktuacja będzie relatywnie niższa, gdy ludzie zadowoleni z wynagrodzenia nie będą czuli potrzeby, by zmienić stanowisko pracy. Pozwoli to zapewnić stabilność organizacji, a pracownika pobudza do działania i rozwijania swoich kompetencji (im lepsze kwalifikacje, tym wyższa płaca). Firma, korzystając ze wzrostu efektywności zasobów ludzkich, poprawia swoją sytuację na rynku poprzez rozwój.

Również funkcja społeczna wynagrodzenia wpływa na funkcjonowanie organizacji. Polega ona na budowaniu oraz wzmacnianiu pozytywnej atmosfery w pracy, zapobiega konfliktom na tle wynagrodzeń.

Zgodnie z Kodeksem pracy, wynagrodzenie wypłacane pracownikom nie może być niższe od minimalnego określonego prawem ${ }^{11}$. Natomiast rzeczywistą wysokość stawek wynagrodzenia oraz innych świadczeń wynikających ze stosunku pracy (na podstawie art. 78 § 2 ustawy z dnia 26 czerwca 1974 roku - Kodeks pracy ${ }^{12}$ ) określa się w trybie przewidzianym w art. $77^{1}-77^{3}$.

Elementem funkcji społecznej będzie zapobieganie spadkowi realnej wartości wynagrodzenia, np. przez wprowadzenie do umów klauzul waloryzacyjnych powiązanych ze wskaźnikiem inflacji.

Spadek wartości wynagrodzenia przyczynia się do spadku motywacji wśród pracowników, a także może budzić ich niezadowolenie z tytułu pogorszenia sytuacji materialnej ich samych oraz ich rodzin.

9 Kreator Kultury, http://kreatorkultury.pl/zarzadzanie-poprzez-motywowanie [dostęp: 17.10.2014].

10 S. Borkowska, Wynagradzanie, [w:] H. Król, A. Ludwiczyński (red.), Zarządzanie zasobami ludzkimi. Tworzenie kapitału ludzkiego organizacji, Wydawnictwo Naukowe PWN, Warszawa 2006, s. 354.

11 Ibidem, s. 357-358.

12 Tekst jedn. Dz.U. z 2014 r., poz. 1502. 
Ponadto funkcja społeczna wynagrodzenia winna zaradzać powstawaniu nierówności wynagrodzeń, gdyż ma to negatywne skutki i może prowadzić do powstawania napięć społecznych ${ }^{13}$.

\section{WSPÓŁCZESNE FORMY WYNAGRODZEŃ}

W oparciu o analizowany temat warto wspomnieć o współczesnych formach wynagrodzeń oraz zastanowić się, która z form znajduje szersze zastosowanie w dzisiejszym świecie.

Jakkolwiek formy wynagradzania zależą w istocie od możliwości danego przedsiębiorstwa, preferencji pracodawcy oraz rodzaju wykonywanej pracy, można wyodrębnić cztery formy wynagrodzeń, zwane tradycyjnymi ${ }^{14}$. Zaliczamy do nich formę czasową - wynagrodzenie za czas wykonywanej pracy (dotyczy prac umysłowych) oraz akordową - zapłata za efekt wykonanej pracy, dość często stosowana w odniesieniu do pracowników fizycznych, jednak jest to forma zanikająca. Kolejne dwie formy zaliczane do tradycyjnych to forma zadaniowa oraz prowizyjna. Forma zadaniowa dotyczy wynagrodzenia za realizację określonego zadania, przy czym najczęściej stosuje się ją w stosunku do pracowników produkcyjnych, natomiast prowizyjna, będąca formą przeciwstawną do czasowej, polega na ustaleniu pracownikom procentowych stawek wynagrodzenia. Na rynku pracy stosuje się przeważnie formy łączone, np. czasowo-premiowa czy czasowo-prowizyjna. Wynika to z faktu, że pojedyncza forma wynagrodzenia, na przykład czasowa, nie oddziałuje dostatecznie motywująco, zatem uzupełniając ją formą premiową zwykle osiąga się większą wydajność pracownika.

Coraz większego znaczenia nabiera tzw. kafeteryjna forma wynagrodzenia. Stosuje się ją zwykle w koncernach oraz firmach o wysokiej pozycji na rynku. Oznacza ona, iż to pracownik wspólnie z pracodawcą określa formę, w jakiej uzyska wynagrodzenie. Część wynagrodzenia zawsze jest wypłacana w formie pieniężnej, natomiast druga część, po odpowiednim rozliczeniu w stosunku do wynagrodzenia płacowego, przekazywana jest pracownikowi w formie świadczenia lub usługi. Przykładowo może to być dodatkowe ubezpieczenie, bezpłatne świadczenia zdrowotne w prywatnej klinice czy opłata czesnego za studia dziecka. Obecnie bardzo popularne są dodatkowe benefity w formie kart sportowych czy biletów na wydarzenia kulturalne ${ }^{15}$.

13 Ibidem, s. 357-358.

14 Ibidem, s. 376-378.

15 B. Lenart, Formy wynagradzania: jakie i kiedy stosować?, http://firma.egospodarka.pl/ 32776,Formy-wynagradzania-jakie-i-kiedy-stosowac,7,47,1.html [dostęp: 20.10.2014]. 


\section{POZAFINANSOWE DETERMINANTY LOJALNOŚCI PRACOWNIKÓW}

Warto motywować pracowników poprzez wzmacnianie ich rozwoju w zespole czy budowanie pozytywnej atmosfery w organizacji. Elastyczność czasu pracy również będzie miała wpływ na pracownika. Umiejętne udzielanie informacji zwrotnej, będące podsumowaniem każdego działania, także przyczynia się do budowania motywacji u zatrudnionego. Ponadto w świetle dzisiejszej konkurencyjności rynku bardzo ważne jest, by mieć świadomość potencjalnej utraty wykwalifikowanego personelu.

Współcześnie podejmuje się działania mające na celu podniesienie stopnia identyfikacji kluczowych pracowników z daną organizacją. Kolejnym rozwiązaniem będzie badanie satysfakcji i zadowolenia kapitału ludzkiego określonych przedsiębiorstw. Przy omawianiu techniki badań satysfakcji pracowników posłużę się opisem kwestionariusza JDI ${ }^{16}$ (Job Descriptive Index), znanym w Polsce jako Indeks Opisu Pracy, którego autorami są Smith, Kendall i Hullin. Autorzy wskazanego kwestionariusza wyróżnili 5 wymiarów, które według nich będą kluczowe do pomiaru satysfakcji z pracy. Zaliczamy do nich: pracę samą w sobie, współpracowników, przełożonych, awans oraz wynagrodzenie. Do tych wymiarów autorzy kwestionariusza dostosowali 72 wskaźniki. Pracownik wypełniający kwestionariusz musi określić, które z 72 wskaźników występują w jego miejscu pracy oraz opatrzyć każdy wskaźnik symbolem „Tak”, „Nie” lub znakiem zapytania, jeśli nie jest pewny właściwej odpowiedzi.

Employee Master Question ${ }^{17}$ to kolejne narzędzie służące do badania postaw pracowników względem miejsca pracy i wykonywanych czynności, a także ich opinii odnośnie funkcjonowania firmy, w której pracują.

Celem takich badań powinno być wzmocnienie więzi pracownika z organizacją poprzez naprawę ewentualnych błędnych założeń oraz pozyskanie od pracownika informacji na temat funkcjonowania organizacji.

\section{WŁAŚCIWE METODY OCENIANIA ZASOBÓW LUDZKICH}

Wątpliwości budzą metody oceny pracowników. Czy wszędzie powinny obowiązywać te same założenia przy procesie oceniania? Czy każde stanowisko powinno mieć oddzielny, określony dobór kryteriów, który będzie podlegał ocenie?

Zgodnie z definicją A. Ludwiczyńskiego, „ocena to sąd wartościujący, wykorzystywany w procesie zarządzania. Powstaje w wyniku porównania cech, kwalifikacji, zachowań czy też efektów pracy konkretnego pracownika w odniesieniu do innych

16 http://researchonline.pl/baza?podkategoria = 2 [dostęp: 9.11.2014].

17 Ibidem [dostęp: 9.11.2014]. 
pracowników, bądź ustalonego wzorca"18, natomiast metoda oceniania to próba odpowiedzi na pytanie, w jaki sposób dokonamy oceny. Opiera się ona na wcześniej założonych kryteriach, celach i zasadach ocen ${ }^{19}$, które stanowią układ odniesienia decydujący w istocie o właściwym doborze metody postępowania w ocenie, co reguluje art. 94 pkt 9 KP.

Ocena dzieli się na bieżącą i okresową. Ocena bieżąca ma charakter ciągły, natomiast okresowa - sformalizowany i jest dokonywana co pewien czas w terminie ustalonym przez pracodawcę i pracownika.

Metody oceniania można podzielić na relatywną i absolutną. Metoda relatywna opiera się na porównaniu pracowników między sobą, w odróżnieniu do metody absolutnej, która zakłada porównanie pracownika z wcześniej wytyczonymi standardami. W zakres podejścia relatywnego wchodzi tzw. ranking. Opiera się on na stworzeniu listy pracowników, od "najlepszego" do „najgorszego”. Kolejną metodą wchodzącą w skład relatywnej będzie system porównywania parami. Zakłada ona porównanie wszystkich pracowników między sobą - pracownik o najwyższej liczbie pozytywnych wskazań zwycięża. Metoda rozkładu normalnego również jest zaliczana do metod relatywnych. Polega na ustaleniu, w którym przedziale rozkładu mieści się pracownik. Na metodę absolutną składa się osiem technik: ocena opisowa (pisemne scharakteryzowanie podejścia pracownika do obowiązków), punktowa skala ocen, skale ważone, testowa metoda oceny (formularz przypomina test, pytania z kilkoma odpowiedziami do wyboru), metoda zdarzeń krytycznych (na formularzu zapisywane są sukcesy i porażki zawodowe pracownika), skale behawioralne (opis zachowań pożądanych i niepożądanych oraz ocena zachowań pracownika), zarządzanie przez cele (wspólne ustalenie celów na najbliższy okres przez pracodawcę i pracownika, a także po wyznaczonym okresie wspólne podsumowanie stopnia realizacji powyższych celów) i metoda Assessment Center, zwana Ośrodkami Oceny lub Oceną Zintegrowaną, która nakłania potencjalnych kandydatów do ćwiczeń indywidualnych oraz grupowych w warunkach zbliżonych do ewentualnego miejsca pracy oraz stosunkowo nowe narzędzie w procesie oceniania, metoda 360 stopni, nazywana również wielopodmiotowym systemem oceny (multi-rater assessment). Ward definiuje ją jako „systematyczne zbieranie danych na temat efektów uzyskiwanych przez osobę lub zespół na podstawie informacji udzielanych przez określone grupy interesów"20. Zakłada ona ocenę bądź zbieranie danych stanowiących podstawę do oceny przez wszystkie grupy interesu. Przykładowo: grupa studencka X wykonuje projekt. Zostanie ona oceniona nie tylko przez nauczyciela prowadzącego, ale również przez inne grupy biorące udział w danym projekcie. Istnieje również metoda oceny 180 stopni, natomiast jest ona niepełna, ponieważ w tym wypadku nie uwzględnia się wszystkich grup interesu.

\footnotetext{
18 H. Król, A. Ludwiczyński, Zarządzanie..., s. 275.

19 Ibidem, s. 289.

20 M. Armstrong, Zarządzanie..., s. 466.
} 
Warto również wspomnieć o kryteriach oceniania. Powinny one udzielać odpowiedzi na pytanie, co zamierzamy ocenić, co będzie naszym celem. Zazwyczaj stosuje się podział kryteriów na cztery grupy: kryteria kwalifikacyjne, behawioralne, osobowościowe oraz efektywnościowe. Są one dopasowywane do specyfiki każdej organizacji, zatem nawet na analogicznych stanowiskach kryteria te mogą się różnić. W kontekście kapitału ludzkiego w danej organizacji można uznać, że kryteria kwalifikacyjne będą w przyszłości podstawą do zdefiniowania potrzeb szkoleniowych. Behawioralne mogą wpływać na wizerunek firmy i dostarczać pracodawcy oceny zwrotnej o zachowaniu pracownika. Kryterium osobowościowe pomoże w ocenie predyspozycji psychicznych kadry kierowniczej oraz dopasowania personelu do wymogów określonych stanowisk. Natomiast kryterium efektywnościowe będzie stanowić podstawę do usprawnienia i ulepszenia systemu motywacji w firmie, a także dostarczy informacji o stopniu zadowolenia pracownika z systemu wynagrodzeń, który przyjęto w danym przedsiębiorstwie ${ }^{21}$.

Właściwy dobór metody oceny zależy od branży przedsiębiorstwa oraz od stopnia stanowiska, które podlega procesowi oceniania.

\section{NORMY PRAWNE REGULUJACE STOSUNKI MIĘDZY PRACODAWCĄ A PRACOWNIKIEM - ELASTYCZNE FORMY ZATRUDNIENIA}

Kolejną niezbędną kwestią, którą należy poruszyć w kontekście właściwego gospodarowania kapitałem ludzkim jest podstawowy przedmiot regulacji prawa pracy, czyli stosunek pracy. Warto zastanowić się, dlaczego obecnie coraz większe znaczenie ma zatrudnienie pracowników na podstawie umów cywilnoprawnych (do najpopularniejszych można zaliczyć: umowę o dzieło, umowę zlecenie, umowę agencyjną, kontrakt) niż umów regulowanych stosunkiem pracy.

Zgodnie z art. $353^{1}$ ustawy z dnia 23 kwietnia 1964 roku - Kodeks cywilny (dalej: KC) ${ }^{22}$ strony zawierające umowę mogą ułożyć stosunek prawny według swojego uznania, z zastrzeżeniem, że treść bądź cel umowy nie może działać w sprzeczności z ustawą, bądź zasadami współżycia społecznego. Art. 11 KP reguluje zasadę swobody nawiązywania stosunku pracy ${ }^{23}$.

W XXI wieku można zaobserwować wyraźny wzrost zainteresowania niepracowniczymi formami zatrudnienia ${ }^{24}$, zatrudnienie nieregulowane przepisami prawa pra-

21 H. Król, A. Ludwiczyński, Zarządzanie..., s. 284-287.

22 Tekst jedn. Dz.U. z 2014 r., poz. 121 ze zm.

23 J. Piątkowski, Aksjologiczne i normatywne podstawy prawa stosunku pracy, TNOiK, Toruń 2013, s. 26.

24 Ibidem, s. 29. 
cy. Przyczyniło się do tego zjawisko liberalizacji zatrudnienia. Nowoczesne formy zatrudnienia często wiążą się z większą elastycznością, zatem przewidują większą swobodę zarówno pracownika, jak i pracodawcy, w przeciwieństwie do przepisów kodeksu pracy ${ }^{25}$.

Istnienie nowych form pracy wymusza niejako wciąż zmieniający się rynek pracy. Globalizacja pociągnęła za sobą takie zjawiska, jak konkurencyjność przedsiębiorstw czy wzrost bezrobocia26. Dzięki elastycznym formom zatrudnienia możliwe jest ograniczenie tych zjawisk poprzez dostosowanie umowy do konkretnych potrzeb pracodawcy i pracownika.

Do jednej z popularniejszych form zatrudnienia zalicza się umowy cywilnoprawne, jednak budzą one sporo kontrowersji, ze względu na brak funkcji ochronnej w stosunku do pracownika. Istnieje obawa wykorzystywania przez pracodawców umów cywilnoprawnych jako środka służącego do omijania prawa oraz zaniżania świadczeń socjalnych. Należy mieć świadomość, że zatrudnienie na umowy cywilnoprawne skutkuje odpowiednio niższymi świadczeniami emerytalnymi w stosunku do umowy o pracę, a także brakiem określonych praw do zasiłku chorobowego, renty czy urlopu. Nie dziwi więc stosowanie w odniesieniu do umów cywilnoprawnych pejoratywnego pojęcia „umów śmieciowych"27.

Walorem zatrudniania pracowników na podstawie umów cywilnoprawnych jest fakt, iż tego typu umowy charakteryzują się zdecydowanie większą elastycznością czasu pracy w stosunku do umowy o pracę. Ich pozytywną cechą jest również: mały stopień zależności zatrudnionego od pracodawcy, natychmiastową możliwość złożenia wypowiedzenia czy brak stosunku podporządkowania.

Pod pojęciem nowoczesnych form zatrudnienia rozumie się również telepracę (forma pracy wykonywanej regularnie poza zakładem pracy, przy zastosowaniu technologii informatycznych i telekomunikacyjnych) ${ }^{28}$, pracę tymczasową (forma chwilowego zatrudnienia) ${ }^{29}$, samozatrudnienie (praca wykonywana na własny rachunek, we własnym imieniu oraz na własne ryzyko ${ }^{30}$, nierzadko związana z prowadzeniem własnej działalności gospodarczej) czy freelancing, czyli możliwość wykonywania pracy jako „wolny strzelec”, w każdym miejscu na ziemi.

Wymienionej powyżej elastyczne formy zatrudnienia wiążą się z postępem technologicznym. Globalizacja skutecznie niweluje przeświadczenie, że czynności zawodowe mogą być wykonywane wyłącznie w miejscu zatrudnienia. Obecne społeczeństwa stały się bardziej mobilne, zatem tworzenie nowoczesnych form zatrudnienia jest swego

25 Ibidem, s. 17-19.

26 Ibidem, s. 19.

27 forsal.pl/artykuly/699684,umowy_smieciowe_w_polsce_umowy_cywilnoprawne_coraz_ bardziej_powszechne.html [dostęp: 17.11.2014].

${ }^{28}$ www.sprawni-niepelnosprawni.pl/pl/artykuly/afz-rodzaje_afz/0/55 [dostęp: 17.11.2014].

29 J. Piątkowski, Aksjologiczne..., s. 46.

30 www.sprawni-niepelnosprawni.pl/pl/artykuly/afz-rodzaje_afz/0/55 [dostęp: 17.11.2014]. 
rodzaju kompromisem dla pracownika i pracodawcy. Dzięki nim pracownik zyskuje większą możliwość pogodzenia życia zawodowego z prywatnym, a pracodawca obniżenie kosztów z tytułu zatrudnienia pracownika.

Wspomniane walory współczesnych form regulujących stosunki zatrudnienia nie są w stanie przysłonić korzyści płynących z tradycyjnego modelu zatrudnienia, czyli umowy o pracę. Prawa i obowiązki pracownika oraz pracodawcy w zakresie umowy o pracę określa Kodeks pracy. Zaletą umowy o pracę jest m.in. ochrona przed rozwiązaniem umowy, gwarancja wynagrodzenia za świadczoną pracę czy możliwość skorzystania z uprawnień, jakie przysługują pracownikowi na podstawie przepisów zawartych w Kodeksie pracy i innych aktach regulujących stosunki zatrudnienia. Natomiast wadą tej formy zatrudnienia jest konieczność określenia w sposób ścisły miejsca pracy i czasu jej wykonywania, a także niemożliwość powierzenia jej przez pracownika innej osobie ${ }^{31}$ (w przeciwieństwie do niektórych umów cywilnoprawnych).

W kontekście tych rozważań warto również wspomnieć o socjalnym modelu zatrudnienia, tzw. flexicurity, który zakłada poszukiwanie kompleksowych rozwiązań korzystnych dla obu stron rynku pracy, m.in. łatwość pozyskania nowych pracowników przez pracodawcę czy system motywujący bezrobotnych do poszukiwania pracy. System flexicurity zakłada tworzenie umów o elastycznej formie, a jednocześnie możliwość zapewnienia pracownikowi bezpieczeństwa zachowania pracy bądź w krótkim okresie możliwość znalezienia nowego miejsca zatrudnienia dla danej osoby ${ }^{32}$.

\section{PODSUMOWANIE}

Z powyższych rozważań wynika, że wzmacnianie wizerunku firmy poprzez działania ukierunkowane na zasoby ludzkie oraz przyjęcie polityki o charakterze nie tylko probiznesowym, ale również propracowniczym, wyraźnie wpłynie na zaangażowanie pracowników. Bardzo ważny charakter motywacyjny realizuje instytucja wynagradzania. Jak podkreślono, obecnie większe znaczenie zyskuje kafeteryjny model wynagradzania pracowników ze względu na dużą różnorodność i atrakcyjność oferty rynkowej.

$\mathrm{Na}$ relację pracownika z firmą ważny wpływ ma właściwy dobór oceny kadry pracowniczej. Jako skuteczną metodę wskazano tzw. ocenę 360 stopni, gdyż daje ona wielopoziomową informację o wartości pracownika. Stwierdzono również, że umiejętność udzielenia kompleksowej informacji o ocenie pracownika znacznie wpłynie na jego stosunek do pracy.

W powyższej pracy odwołano się do wzrostu znaczenia stosunków zatrudnienia we współczesnym świecie. Założono, że coraz większa popularność nowych form

31 http://kadry.infor.pl/kadry/poradniki/poradnik/676788,2,Umowy-cywilnoprawne-zasadyzawierania-i-praktyczne-rozliczenia.html [dostęp: 18.11.2014].

32 http://ec.europa.eu/polska/news/opinie/110107_flexicurity_pl.htm [dostęp:18.11.2014]. 
zatrudnienia jest skutkiem ciągłych zmian i postępu na rynku pracy, m.in. poprzez częstsze wykorzystanie niezależnej formy zatrudnienia, np. freelancingu, a także wiąże się z mniejszymi kosztami, jakie ponosi pracodawca z przyczyn zatrudnienia niepracowniczego w stosunku do zatrudnienia na podstawie umowy o pracę. W związku z powyższym należy wysunąć wniosek, iż w kolejnych latach popularność zatrudnienia niepracowniczego zwiększy się kosztem tradycyjnego stosunku pracy.

\section{BIBLIOGRAFIA}

Armstrong M., Zarządzanie zasobami ludzkimi, Oficyna Ekonomiczna, Kraków 2007.

Król H., Ludwiczyński A., Zarządzanie zasobami ludzkimi. Tworzenie kapitału ludzkiego organizacji, Wydawnictwo Naukowe PWN, Warszawa 2006.

Piątkowski J., Aksjologiczne i normatywne podstawy prawa stosunku pracy, TNOiK, Toruń 2013.

Grodzicki J., Rola kapitału ludzkiego w rozwoju gospodarki globalnej, Wydawnictwo Uniwersytetu Gdańskiego, Gdańsk 2003.

\section{Źródła internetowe}

http://forbes.pl/artykuly/sekcje/baza-wiedzy-csr/czym-jest-odpowiedzialnosc-spoleczna-biznesu-csr--ang--corporate-social-responsibility-,3878,1\#

http://forsal.pl/artykuly/699684,umowy_smieciowe_w_polsce_umowy_cywilnoprawne_coraz_bardziej_powszechne.html

http://kadry.infor.pl/kadry/poradniki/poradnik/676788,2,Umowycywilnoprawne-zasady-zawierania-i-praktyczne-rozliczenia.html

http://ec.europa.eu/polska/news/opinie/110107_flexicurity_pl.htm

http://kreatorkultury.pl/zarzadzanie-poprzez-motywowanie

Lenart B., Formy wynagradzania: jakie i kiedy stosować?, http://firma.egospodarka. pl/32776, Formy-wynagradzania-jakie-i-kiedy-stosowac, 7,47,1.html www.sprawni-niepelnosprawni.pl/pl/artykuly/afzrodzaje_afz/0/55

http://researchonline.pl/baza?podkategoria $=2$

http://preals.pl/predu/definicja-pr

\section{Akty prawne}

Dz.U. z 2014 r., poz. 121 ze zm. 